\title{
Occurrence, physiological responses and toxicity of nickel in plants
}

\author{
T. V. M. Sreekanth $\cdot$ P. C. Nagajyothi $\cdot$ K. D. Lee $\cdot$ \\ T. N. V. K. V. Prasad
}

Received: 9 October 2011/Revised: 14 March 2012/Accepted: 13 May 2012/Published online: 29 March 2013

(C) Islamic Azad University (IAU) 2013

\begin{abstract}
The focus of the review is on the specific aspects of nickel's effects on growth, morphology, photosynthesis, mineral nutrition and enzyme activity of plants. The mobility of nickel in the environment and the consequent contamination in soil and water is of great concern. Also, the detrimental effects of excessive nickel on plant growth have been well known for many years. Toxic effects of nickel on plants include alterations in the germination process as well as in the growth of roots, stems and leaves. Total dry matter production and yield was significantly affected by nickel and also causes deleterious effects on plant physiological processes, such as photosynthesis, water relations and mineral nutrition. Nickel strongly influences metabolic reactions in plants and has the ability to generate reactive oxygen species which may cause oxidative stress. More recent evidence indicates that nickel is required in small amounts for normal plant growth and development. Hence, with the increasing level of nickel pollution in the environment, it is essential to understand the functional roles and toxic effects of nickel in plants.
\end{abstract}

Keywords Higher plants · Micronutrient . Mechanisms of activity $\cdot$ Nickel $\cdot$ Oxidative stress

T. V. M. Sreekanth · P. C. Nagajyothi - K. D. Lee Department of Nanomaterial Chemistry, Dongguk University, Gyeongju, South Korea

T. N. V. K. V. Prasad ( $\square)$

Institute of Frontier Technology, Regional Agricultural Research

Station, Acharya N G Ranga Agricultural University,

Tirupati 517 502, A.P., India

e-mail: tnvkvprasad@gmail.com

\section{Introduction}

In recent years, as a result of uncontrolled industrial development worldwide, many chemical substances have resulted in significant air, water and soil pollution, to such an extent that environmental pollution is now a serious worldwide problem. Nickel (Ni) is just one of a variety of ubiquitous trace metals emitted into the environment from both natural and anthropogenic sources (WHO 1991). Of particular concern is the increasing concentration of $\mathrm{Ni}$ deposited in agricultural soils by airborne $\mathrm{Ni}$ particles. The primary sources of $\mathrm{Ni}$ emissions into the ambient air are combustion of coal and oil for heat or power generation, Ni mining, steel manufacture, and other miscellaneous sources, such as cement manufacture. Chiefly found in pentlandite $\left[(\mathrm{Ni}, \mathrm{Fe})_{9} \mathrm{~S}_{8}\right]$ and garnierite ores $(\mathrm{Ni}, \mathrm{Mg})_{3} \mathrm{Si}_{2} \mathrm{O}_{5}(\mathrm{OH})_{4}$, annual world production is over $1,300,000$ tons where the primary mining areas are in Australia, Canada, Cuba, Indonesia, New Caledonia, Russia, South Africa and, the USA (Table 1). In polluted air, the predominant $\mathrm{Ni}$ compounds are nickel sulfates, oxides and sulfides, and to a lesser extent, metallic nickel (WHO 1991). Although generally established far from city centres, cement factories are one manufacturing industry commonly associated with particulate pollution and as a result significantly affect the local areas, where cement dusts can be spread over a large area via wind and rain, and are accumulated on plants and soils (Ayvaz 1992).

Nickel is the 28th element of the periodic table. It is a silver-white metal found in several oxidation states (ranging from -1 to +4 ); however, the +2 oxidation state $[\mathrm{Ni}(\mathrm{II})]$ is the most common one in biological systems (Denkhaus and Salnikow 2002). Nickel readily forms nickel-containing alloys, which over the last 100 years have found an ever increasing variety of uses in modern 
Table 1 World mine production of nickel (National Academy of Sciences 1975; International Agency for Research on Cancer 1976; Duke 1980; Kasprzak 1987; WHO 1991; Ronald Eisler 1998)

\begin{tabular}{lr}
\hline Years & Metric tons \\
\hline 1900 & 7,500 \\
1925 & 42,700 \\
1950 & 141,000 \\
1970 & 694,100 \\
1975 & $753,000^{\mathrm{a}}$ \\
1980 & 84,100 \\
1985 & $821,000^{\mathrm{b}}$ \\
2000 (projected) & $>2,000,000$ \\
\hline
\end{tabular}

${ }^{a}$ About $32 \%$ from Canada, $18 \%$ from New Caledonia, $17 \%$ from the former Soviet Union, $10 \%$ from Australia, $5 \%$ from Cuba, $4 \%$ from the Dominican Republic, $3 \%$ from the Republic of South Africa, $2 \%$ each from Greece, Indonesia, and the United States, and $5 \%$ from other countries

b Mostly from Canada, the former Soviet Union, Australia, and Cuba, in that order. The United States produced 6,900 tons in 1985

technologies. Global input of Ni to the human environment is approximately 150,000 and 180,000 metric tonnes per year from natural and anthropogenic sources, respectively, including emissions from fossil fuel consumption, and industrial production, use, and disposal of $\mathrm{Ni}$ compounds and alloys (Kasprzak et al. 2003).

Plants require access to a variety of common minerals to attain good growth. The micronutrients which are needed only in trace amounts include boron (B), chloride $(\mathrm{Cl})$, cobalt $(\mathrm{Co})$, copper $(\mathrm{Cu})$, iron $(\mathrm{Fe})$, manganese $(\mathrm{Mn})$, molybdenum (Mo), nickel (Ni), selenium (Se), silicon (Si), sodium ( $\mathrm{Na}$ ) and zinc $(\mathrm{Zn})$. The term "essential" mineral elements (or mineral nutrients) were first proposed by Arnon and Stout (1939) who concluded that three criteria must be met for an element to be considered essential.

1. A plant must be unable to complete its life cycle in the absence of that mineral element,

2. The function of the element must not be replaceable by another mineral element and

3. The element must be directly involved in plant metabolism.

The importance of micro-elements

Although required in only minor quantities, micro-elements are incredibly important for plant nutrition. This importance was first understood in 1840 by the German chemist, Freiherr Justus von Liebig, who made major contributions to Agricultural Science and Biological Chemistry. Liebig's Law of the Minimum, often simply called as Liebig's Law, is an agricultural principle that states that if one of the nutritive elements is deficient, plant growth will be restricted even when all the other elements are abundant. Thus, any deficiency of a nutrient, no matter how small will inhibit plant development. If the deficient element is supplied, growth will consequently increased up to the point where the supply of that element is no longer the limiting factor. Increasing the nutrient supply beyond the limiting point will not normally be helpful, because other elements would likely become in minimum supply and become the limiting factor.

Plant nutrient uptake

Plants can absorb nutrients only from the soil solution phase and cannot directly access nutrients from the soil solid phase. Thus, the problem with accessing micro-elements is their limited solubility of solid phase nutrients, which limits their presence in soil solution. Plant uptake from soil solution occurs in three major ways: root interception, mass flow and diffusion.

During root interception, as the roots proliferate through the soil, they move into spaces previously occupied by soil containing available nutrients, for example, absorbed by clay particles and the root surfaces intercept nutrients during this displacement process (Barber 1984). During mass flow, movement of water and dissolved nutrients into plants is driven by the plants transpiration gradient and simple diffusion allows movement of nutrients according to differential concentration gradients from high to low concentrations.

\section{Sources}

Nickel is a ubiquitous trace metal emitted into the environment from both natural and anthropogenic sources (Table 2) which are found in soil, water and air samples within the biosphere (Barrie 1981; WHO 1991). The compounds such as nickel acetate, nickel carbonate, nickel hydroxide and nickel oxide are used in a variety of industrial process (Cempel and Nikel 2006). These compounds ultimately accumulate in the soil and environment, and can be easily taken up by plants. Thus, they can enter the food chain and cause deleterious effects to animals and human (Nieboer and Nriagu 1992; Cempel and Nikel 2006). While the level of $\mathrm{Ni}$ in ambient air is generally small (about 6-20 $\mathrm{ng} \mathrm{m}^{-3}$ ), levels up to $150 \mathrm{ng} \mathrm{Ni} \mathrm{m}^{-3}$ could be present in air contaminated by anthropogenic sources. In water, $\mathrm{Ni}$ derives from biological cycles and solubilization of nickel compounds from soils, as well as from the sedimentation of $\mathrm{Ni}$ from the atmosphere. Uncontaminated water usually contains about $300 \mathrm{ng} \mathrm{dm}^{-3} \mathrm{Ni}$. Farm soils contain approximately $3-1,000 \mathrm{mg} \mathrm{kg}^{-1} \mathrm{Ni}$ soil, but the $\mathrm{Ni}$ 
Table 2 Inventory of nickel in various global environmental compartments (modified from Nriagu 1980)

\begin{tabular}{llr}
\hline Compartment & $\begin{array}{l}\text { Mean } \\
\text { concentration } \\
(\mathrm{mg} / \mathrm{kg})\end{array}$ & $\begin{array}{r}\text { Nickel in compartment } \\
\text { (metric tons) }\end{array}$ \\
\hline Lithosphere, down to $45 \mathrm{~km}$ & 75 & $4,300,000,000,000,000$ \\
Sedimentary rocks & 48 & $120,000,000,000,000$ \\
Soils, to $100 \mathrm{~cm}$ & 16 & $5,300,000,000,000$ \\
Oil shale deposits & 30 & $1,400,000,000,000$ \\
Dissolved oceanic & 0.0006 & $840,000,000$ \\
Nickel ore reserves & $>2,000$ & $160,000,000$ \\
Coal deposits & 15 & $150,000,000$ \\
Terrestrial litter & 15 & $33,000,000$ \\
Terrestrial plants & 6 & $14,000,000$ \\
Suspended oceanic & 95 & $6,600,000$ \\
particulates & & $2,300,000$ \\
Crude oil & 10 & 50,000 \\
Terrestrial animals & 2.5 & 42,000 \\
Swamps and marshes & 7 & 34,000 \\
Lakes and rivers, total & 0.001 & 11,000 \\
Consumers/reducers & 3.5 & \\
$\quad$ biological) & 0.3 & 1,500 \\
Atmosphere & 2.5 & 500 \\
Oceanic plants & 4 & 230 \\
Lakes and rivers, plankton & & \\
\hline & &
\end{tabular}

concentration can reach up to $24,000 \mathrm{mg} \mathrm{kg}^{-1} \mathrm{Ni}$ in soil near metal refineries and $53,000 \mathrm{mg} \mathrm{kg}^{-1} \mathrm{Ni}$ in dried sludge. At $\mathrm{pH}<6.5$, Ni compounds present in soil are relatively soluble, whereas at $\mathrm{pH}>6.7$, most $\mathrm{Ni}$ exists as insoluble hydroxides.

\section{Nickel toxicity to plants}

Nickel is a heavy metal and an essential microelement for plants, animals, and humans, but toxic at high concentrations, exceeding optimum intake values. As with other heavy metals, excess concentrations of $\mathrm{Ni}$ in plants cause chlorosis and necrosis, due to disruption of Fe uptake and metabolism (De kock 1956; Crooke 1958). Elevated concentrations of $\mathrm{Ni}$ can inhibit cell division at root meristems in non-tolerant plants (Robertson and Meakin 1980), and decrease plant growth (Foy et al. 1978). Previous studies have also shown that $\mathrm{Ni}$ has a negative effect on photosynthesis and respiration (Carlson et al. 1975). Nickel is an important metal for metabolism because $\mathrm{Ni}$ is a major component of plant enzymes (Fig. 1). For instance, $\mathrm{Ni}$ is a constituent of urease, and small quantities of $\mathrm{Ni}(0.01-5 \mu \mathrm{g} / \mathrm{g}$ dry wt) are essential for some plant species.
$\mathrm{Ni}^{2+}$ concentrations in polluted soil may reach levels 20- to 30 -fold higher $(200-26,000 \mathrm{mg} / \mathrm{kg}$ ) than the range typically found in natural soils $(10-1,000 \mathrm{mg} / \mathrm{kg})$ (Izosimova 2005). Elevated levels of $\mathrm{Ni}$ in soil may cause various physiological alterations and diverse toxicity symptoms such as chlorosis and necrosis in a variety of plant species (Zornoza et al. 1999; Pandey and Sharma 2002), rice (Samantaray et al. 1997). Plants grown in high $\mathrm{Ni}^{2+}$ containing soil showed impairment of nutrient balance and resulted in disorder of cell membrane function. Thus, $\mathrm{Ni}^{2+}$ affected the lipid composition and H-ATPase activity of the plasma membrane as reported in Oryza sativa shoots (Ros et al. 1992). Exposure of wheat to high level of $\mathrm{Ni}^{2+}$ enhanced MDA concentration (Pandolfini et al. 1992). Moreover, Gonnelli et al. (2001) reported an increase in MDA concentration of $\mathrm{Ni}^{2+}$ sensitive plants compared to a $\mathrm{Ni}^{2+}$ tolerant Silene paradox. Such changes might disturb membrane functionality and ion balance in the cytoplasm, particularly of $\mathrm{K}^{+}$, the most mobile ion across plant cell membranes. Other symptoms observed in $\mathrm{Ni}^{2+}$ treated plants were related with changes in water balance. High uptake of $\mathrm{Ni}^{2+}$ induced a decline in water content of dicot and monocot plant species (Dimkpa et al. 2008). The decrease in water uptake was used as an indicator of $\mathrm{Ni}^{2+}$ toxicity in plants (Pandey and Sharma 2002; Gajewska et al. 2006).

\section{Effect on plant growth}

The toxic effects of $\mathrm{Ni}$ and other heavy metals are primarily manifested by the inhibition of plant growth (Seregin and Ivanov 2001; Seregin et al. 2003; Pandolfini et al. 1992; Nagajyoti et al. 2010), an index widely employed to assess environmental pollution (Wang 1987). Growth inhibition gains strength at higher metal concentration (Wang 1987; Samantaray et al. 1997; Yusuf et al. 2011). In excluder species, which accumulate $\mathrm{Ni}$ mostly in their roots, root growth is inhibited more heavily than the growth of shoots (Seregin et al. 2003; Sresty and Madhava Rao 1999; Wong and Bradshaw 1982; Samantaray et al. 1997), and therefore the root test is widely used for evaluating the toxicity of various agents, including heavy metals (Seregin et al. 2003; Wong and Bradshaw 1982; Wang 1987). The tolerance index was determined between the root/shoot length of the heavy metal-stressed plant and that of the control plant (Samantaray et al. 1997), and LC50, the metal concentration that inhibits root growth by $50 \%$, are the indices of plant tolerance toward heavy metals (Wong and Bradshaw 1982; Wang, 1987). Using the latter index, Wong and Bradshaw arranged metals in decreasing toxicity to root growth order $\mathrm{Cu}>\mathrm{Ni}>\mathrm{Mn}>\mathrm{Pb}>\mathrm{Cd}>\mathrm{Zn}>$ $\mathrm{Al}>\mathrm{Hg}>\mathrm{Cr}>\mathrm{Fe}$ for Lolium perenne seedlings (Wong and Bradshaw 1982). This order will vary with different 
Fig. 1 Mechanisms mediating toxic effects of excess $\mathrm{Ni}$ in plants (Chen et al. 2009)

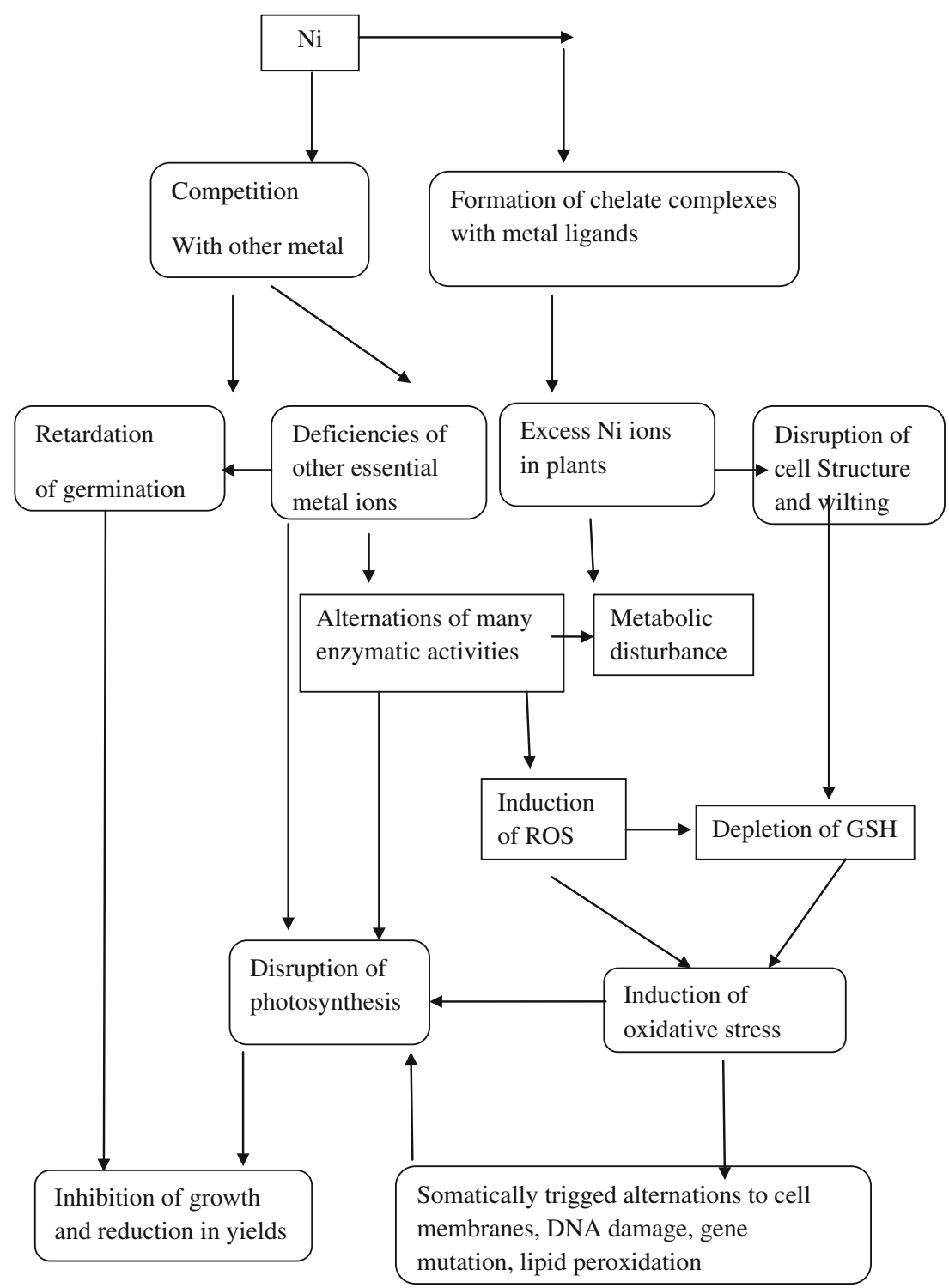

plant species (Neiboer and Richardson 1980; Karataglis et al. 1986), since plant species differ in their innate metal tolerance. However, such orders do not always reflect genuine toxicity effects since some authors used the weight rather than molar concentrations of metals (Seregin and Ivanov 2001). Comparison of LC50 indices in diverse plant species allows plants to be classified into tolerant (Cucumis sativus and Panicum miliaceum) and less tolerant species (Chloris gayana, Lactuca sativa, Lolium perenne, Panicum maximum, and Zea mays) that have a LC50 value lower by an order of magnitude (Wong and Bradshaw 1982; Wang 1987). Unlike root growth, the process of lateral root initiation is very resistant to the most heavy metals (Seregin and Ivanov 2001; Ivanov 1994), due to the endodermal barrier and the characteristic structure of the central cylinder cells (Seregin and Ivanov 1997, 1998). However, $\mathrm{Ni}^{2+}$ considerably decreased the number of lateral roots in rice and maize (Seregin et al. 2003; Samantaray et al.1997), apparently because $\mathrm{Ni}$ can cross the endodermal barrier and accumulate in the pericycle cells. Beside root growth, $\mathrm{Ni}^{2+}$ reportedly exerts considerable inhibitory effects on shoot growth and morphogenesis in Phaseolus vulgaris (Piccini and Malavolta 1992), Digitaria sanguinolis, Cyperus difformis, and Chenopodium ambrosioides (Ewais 1997). The total growth inhibition in P. vulgaris also affected seed formation (Piccini and Malavolta 1992). Seed germination is the most resistant indices to heavy metal exposure. The caryopses of rice (Das et al. 1978) and maize (Seregin and Kozhevnikova 2005) germinated at high concentrations of $\mathrm{Ni}$ salts $\left(10^{-2} \mathrm{M}\right)$. 
Effect on morphology

In addition to toxic effects on growth, heavy metals may induce changes in plant morphology and anatomy. Thus, exposure to $1 \mathrm{mM} \mathrm{NiSO}_{4}$ solution decreased the mesophyll thickness, the size of vascular bundles, the vessel diameter in the main and lateral vascular bundles, and the width of epidermal cells in Triticum aestivum leaves (Seregin and Kozhevnikova 2006a, b), whereas in the leaves of Brassica oleracea plants grown in agar in the presence of $\mathrm{NiSO}_{4} \cdot 7 \mathrm{H} 2 \mathrm{O}\left(10-20 \mathrm{~g} / \mathrm{m}^{3}\right)$, the volumes of intercellular spaces and palisade and sponge mesophyll decreased relative to control plants (Molas 1997). In addition to general metabolic disorder, heavy metals are known to decrease the plasticity of cell walls, probably by direct binding to pectines and by promoting peroxidise activity in the cell walls and intercellular space. These peroxidases are essential for lignification and linkage between extensin and polysaccharides containing ferulic acid (Pandolfini et al. 1992). Another way to inhibit growth is by hampering cell division (Robertson and Meakin 1980; L'Huillier et al. 1996; Knasmüller et al. 1998; Amosova et al. 2003). The incubation on $1.5-5 \mathrm{mM} \mathrm{NiCl}_{2}$ solution decreased the mitotic index in Vicia faba roots (Knasmüller et al. 1998), and at a concentration of $60 \mathrm{mM}$, in Z. mays roots (L'Huillier et al. 1996). At a concentration of $0.1 \mathrm{mM}, \mathrm{NiSO}_{4}$ cell divisions were blocked in the rhizoderm, exoderm, middle cortex, except in the distal cells of these tissues, and in the peripheral cells of caliptrogen in the embryonic root of T. aestivumi (Seregin and Kozhevnikova 2006a, b). The inhibition of cell division was frequently accompanied by disorganization of nuclear structures. Thus, in the root tips of Cajanus cajan plants grown in the presence of $1.5 \mathrm{mM}$ $\mathrm{NiSO}_{4} \cdot 6 \mathrm{H} 2 \mathrm{O}$, two nucleoli developed in the nucleus, the chromatin became exceedingly condensed, and the nuclear membrane was disrupted (Sresty and Madhava Rao 1999).

Heavy metals may cause mitosis disorder and chromosome aberrations. For example, in the meristematic cells of Allium cepa root, $\mathrm{Ni}^{2+}(10-100 \mu \mathrm{M})$ produced various chromosome aberrations: C-metaphases, sticky chromosomes, and chromosome bridges, while the interphase cells contained micronuclei. At high $\mathrm{Ni}^{2+}$ concentrations $(1-10 \mathrm{mM})$, the nuclear material was found in the cytoplasm, whereas the nuclei contained nucleoli of irregular form (oval, oblong, and dumbbell like). Similar changes were observed in plant cells exposed to other heavy metals; however, the extent of damage depended on concentration and became the basis for ordering the metals by decreased mutagenic effect (the minimum toxic concentration is listed in parentheses): $\mathrm{Hg}^{2+}$ and $\mathrm{Cd}^{2+}\left(10^{-7}-10^{-5} \mathrm{M}\right)$ $>\mathrm{Zn}^{2+}, \mathrm{Pb}^{2+}, \mathrm{Cu}^{2+}, \mathrm{Ni}^{2+}, \mathrm{Co}^{2+}, \mathrm{Al}^{3+}$ and $\mathrm{Cr}^{3+}\left(10^{-4}-\right.$ $\left.10^{-3} \mathrm{M}\right)>\mathrm{Mn}^{2+}$ and $\mathrm{Mg}^{2+}\left(10^{-2} \mathrm{M}\right)$ (Liu et al. 1995). Plant growth inhibition by $\mathrm{Ni}$ and other heavy metals results from general metabolic disorder and immediate inhibition of cell divisions. However, it is not clear whether $\mathrm{Ni}$ enters cell nuclei at high concentrations and, if it does, how important is immediate Ni interaction with DNA and nuclear proteins. The possible effect of $\mathrm{Ni}^{2+}$ on fragmoplast formation is also unknown. By elucidating these issues, we will better understand the toxic effects of $\mathrm{Ni}$ on plant growth and morphogenesis.

\section{Inhibition of photosynthesis}

Heavy metals are known to cause non-specific inhibition of photosynthesis, by several direct and indirect means. The diminished rate of photosynthesis is related to disrupted chloroplast structure, blocked chlorophyll synthesis, disordered electron transport, inhibited activities of the Calvin cycle enzymes, and $\mathrm{CO}_{2}$ deficiency caused by stomatal closure (Seregin and Ivanov 2001). The decrease in chloroplast size and numbers and the disorganization of chloroplast ultra structure were reported in B. oleracea plants grown in agar in the presence of $\mathrm{NiSO}_{4} \cdot 7 \mathrm{H} 2 \mathrm{O}$ at $10-20 \mathrm{~g} / \mathrm{m}^{3}$. Other changes such as diminished numbers of grana and thylakoids, their deformation, the formation of plastoglobuli, and the changes in the membrane lipid composition were also observed in the Brassica plants. Such changes arose from either the Ni-induced decline in cell moisture content or from an oxidative stress resulting in peroxidation of membrane lipids (Molas 1997). Several authors reported diminished chlorophyll content in the leaves of Ni-treated plants, where such chlorosis could result from both $\mathrm{Fe}$ and $\mathrm{Mg}$ deficiency and the inhibition of chlorophyll synthesis (Ewais 1997; Piccini and Malavolta 1992). The disruption of electron transport exemplifies another mechanism that hampers photosynthesis. Numerous experiments demonstrated that $\mathrm{Ni}^{2+}$, as with other heavy metals, primarily affects PSII (Seregin and Ivanov 2001; Veeranjaneyulu and Das 1982; Mohanty et al. 1989; Krupa and Baszynski 1995; Maksymiec 1997); this evidence is in line with the predominant $\mathrm{Ni}$ accumulation in the PSII-containing lamella regions (Veeranjaneyulu and Das 1982). When inspected in more detail, Ni was shown to inhibit electron transport from pheophytin via plastoquinone $\mathrm{QA}$ and $\mathrm{Fe}$ to plastoquinone $\mathrm{QB}$ by changing the structure of carriers, such as plastoquinone QB, or the reaction center proteins (Mohanty et al. 1989; Krupa et al. 1993). In the thylakoids, Ni ions also decreased the contents of cytochromes b6f and b559, as well as ferredoxin and plastocyanin and as a result, the efficiency of electron transport decreased (Veeranjaneyulu and Das 1982). By inhibiting key enzyme activities of the Calvin cycle, such as Rubisco, 3-phosphoglycerate kinase, fructose-1,6-bisphosphatase, aldolase, and NAD- and NADP-dependent phosphoglyceraldehyde dehydrogenases, heavy metals can 
inhibit photosynthesis. Such effects were demonstrated in C. cajan leaves following several days of incubation with $1 \mathrm{mM} \mathrm{NiCl}_{2}$ solution (Sheoran et al. 1990). The inhibition of Calvin cycle reactions would lead to the accumulation of ATP and NADPH produced by photosynthetic reactions; the latter, in their turn, develop a high $\mathrm{pH}$ gradient across the thylakoid membrane that blocks PSII activity (Krupa and Baszynski 1995). Another mechanism inhibiting photosynthesis stems from stomatal closure in Ni-stressed plants that limits plant $\mathrm{CO}_{2}$ uptake (Sheoran et al. 1990; Bishnoi et al. 1993). The toxic effects of heavy metals on many other metabolic processes would amplify the direct inhibition of photosynthesis.

\section{Effect on mineral nutrition}

One of the non-specific mechanisms of heavy metal toxicity is the reduction of cation and anion absorption by plant roots (Pallavi and Ram Shankar 2005). The published literature on the effects of $\mathrm{Ni}$ on plant mineral nutrition is rather contradictory. In the presence of $\mathrm{Ni}$, the contents of mineral nutrients in plant organs may increase, decrease, or be unaffected. One of the probable mechanisms for decreasing the uptake of macro- and micro-nutrients by $\mathrm{Ni}$ relies on the competition for common binding sites due to comparable ionic radii of $\mathrm{Ni}^{2+}$ and other cations. Such mechanisms may have operated when the uptake of $\mathrm{Mg}^{2+}$ (78 pm), $\mathrm{Fe}^{2+}(82 \mathrm{pm})$, and $\mathrm{Zn}^{2+}(83 \mathrm{pm})$ decreased in the presence of $\mathrm{Ni}^{2+}(78 \mathrm{pm})$ where the ionic radii in parentheses (Emsley, 1991). The reduced uptake of $\mathrm{Mg}$ and $\mathrm{Fe}$ is one of the prime causes of chlorosis induced by excess of environmental Ni (Piccini and Malavolta 1992; Khalid and Tinsley 1980). The decline in nutrient uptake may also result from $\mathrm{Ni}$-induced metabolic disorders that affect the structure and enzyme activities of cell membranes (Seregin and Ivanov 2001). Thus, $\mathrm{Ni}^{2+}$ affected the sterol and phospholipid composition of the plasma membrane in $O$. sativa shoots, with concomitant changes in the ATPase activity (Ros et al. 1990). Apparently, these changes affected the membrane permeability and in this way changed the ion balance in the cytoplasm. The effects of $\mathrm{Ni}$ on nutrient uptake depend on the $\mathrm{Ni}$ concentration in the environment. Experiments with ryegrass demonstrated that $\mathrm{Fe}$ content in the shoots increased at low Ni concentrations and decreased at higher concentrations (Khalid and Tinsley 1980). An increase in soil Ni content from 50 to $200 \mathrm{mg} / \mathrm{kg}$ soil decreased the contents of $\mathrm{Cu}$ and $\mathrm{Mg}$ in the caryopses and $\mathrm{Mg}$ and $\mathrm{Ca}$ in the shoots of T. aestivum (Barsukova and Gamzikova 1999). Rubio and Pandolfini concluded that at high $\mathrm{Ni}$ concentrations (about $0.1-1 \mathrm{mM}$ ), the contents of macro and micro-nutrients in plant tissues are usually lowered because of disordered absorption and transport (Rubio et al. 1994; Pandolfini et al. 1992). At the same time, at low $\mathrm{Ni}$ concentrations in the environment (10-1 $\mu \mathrm{M})$, the contents of nutrients did not change and in some cases even increased (Piccini and Malavolta 1992; Barsukova and Gamzikova 1999). Such a phenomenon was described as a "concentrating effect", because they were observed as a result of growth inhibition (dry biomass decreases) in the plants that were grown in nutrient solutions low in Ni. While the rate of metal absorption stayed the same in the control plants, consequently, the contents of heavy metals increased per unit of dry matter (Piccini and Malavolta 1992). Identical Ni concentrations would have different effects on different plant species. For example, when T. aestivum and T. durum were exposed to $67 \mu \mathrm{M} \mathrm{Ni}$, $\mathrm{Ca}$ and $\mathrm{Mg}$ concentrations increased in both species while $\mathrm{Zn}$ concentrations decreased in the leaves of T. aestivum but remained unchanged in T. durum (Barsukova and Gamzikova, 1999). Toxic Ni concentrations specifically affect the ionic balance in various plant organs. The contents of $\mathrm{Fe}, \mathrm{Mn}$, and $\mathrm{Zn}$ decreased in T. aestivum leaves at the tillering stage, while only Mn content declined in the roots (Barsukova and Gamzikova 1999). Plant species which are tolerant to $\mathrm{Ni}$ may differ in their changes in mineral contents as affected by $\mathrm{Ni}$ than plant species susceptible to Ni. This susceptible genotype also manifested $\mathrm{Mn}$ and $\mathrm{Mg}$ deficiency in the leaves, resulting in chlorosis (Barsukova and Gamzikova 1999).

\section{Effect of nickel on enzyme activity}

As with many other heavy metals, Ni affects various physiological processes in plants, including enzyme activities (Van Assche and Glijsters 1990). However, it is not always easy to differentiate between the direct and indirect effects of heavy metals on enzyme activities. Indirect effects arise from ion-induced imbalances due to competitive inhibition of absorption and transport of nutrients such as $\mathrm{Cu}, \mathrm{Fe}$ and $\mathrm{Zn}$. Direct effects of heavy metals inhibit enzymes by interacting with the $\mathrm{SH}$ groups of proteins, altering protein conformation and thereby causing inactivation of the enzymes. Presently, about a hundred enzymes are known to be inhibited by SH-group binding resulting in concomitant metabolic disorders (Muhammad Sajid and Muhammad 2012). When Z. mays seedlings were incubated in solutions of $\mathrm{Ag}, \mathrm{Cd}, \mathrm{Co}, \mathrm{Cu}$, $\mathrm{Hg}, \mathrm{Pb}, \mathrm{Tl}$ and $\mathrm{Zn}$ salts $(0.001-3 \mathrm{~g} / \mathrm{l})$, the affinity of metals for SH-groups was found to significantly correlated with the molar concentrations that inhibited growth by $50 \%$ (Ivanov et al. 2003). Binding of $\mathrm{SH}$ groups by $\mathrm{Ni}^{2+}$ is one of the mechanisms proposed for the in vitro $\mathrm{Ni}$ toxicity towards $\mathrm{Mg}^{2+}$-dependent ATPases of the plasmalemma; however, $\mathrm{Ni}^{2+}$ may also directly bind to ATP and in this way deplete the substrate pool of ATPase (Ros et al. 1992). While the affinity of $\mathrm{Ni}^{2+}$ for sulfhydryl groups is lower 
than that of other heavy metals, the affinity of Ni for histidine exceeds that of both $\mathrm{Cd}$ and $\mathrm{Pb}$, and therefore, inhibition of enzyme activity by $\mathrm{Ni}$ may result from the interaction with histidine. The toxic effects of metals on enzyme activity in vitro do not always agree with the in vivo effects at the same salt concentration. Such disagreement may stem from the presence of efficient cellular mechanisms for detoxification and the physiological barriers that curb metal translocation into the cytoplasm. To illustrate, $\mathrm{Ni}^{2+}$ was shown to promote in vivo $\mathrm{Mg}^{2+}$. dependent ATPases in the plasmalemma of $O$. sativa shoots (Ros et al. 1990). Total decline of enzyme activities is sometimes observed due to decreased enzyme contents. Thus, the decrease in nitrate reductase activity in soilgrown Beta vulgaris plants following the addition of $1 \mathrm{mM}$ $\mathrm{NiSO}_{4}$ resulted from the diminished rates of nitrate uptake and translocation into the shoots wherein nitrate is reduced. Nitrate in the cytoplasm induces the expression of the nitrate reductase gene, and hence it is the shortage of nitrate in the cells that would primarily decrease the enzyme concentration. Besides, glutamine synthetase and alanine aminotransferase activities were also lowered and in this case, both activities depended significantly on the cytoplasmic levels of nitrate and their substrates (Kevresan et al. 1998; El-Shintinawy and El-Ansary 2000). Similar mechanism of indirect influence on nitrate reductase activity was established for other heavy metals (Pallavi and Ram Shankar 2005). Depending on its concentration, Ni ions can both stimulate and inhibit enzyme activities in plant tissues. Thus, the activities of IAA oxidase, ascorbate oxidase, catalase, and peroxidase in $O$. sativa seedlings were at their highest when exposed to $50 \mu \mathrm{M} \mathrm{NiCl}_{2}$, but the enzyme activities considerably declined at a higher $\mathrm{Ni}$ concentration and were promoted at lower Ni concentrations. In addition, it was shown that Ni did not affect these enzymes directly: under in vitro conditions, the same $\mathrm{Ni}$ concentrations did not produce any visible inhibition of enzyme activities (Das et al. 1978). Enzyme in vivo resistance to $\mathrm{Ni}$ varies with plant development stage. Thus, in $C$. cajan leaves collected from young plants (30 days after sowing), Ni inhibited the activities of the Calvin cycle enzymes. Meanwhile, the inhibitory effect was insignificant when Ni salt was added at later developmental stages (70 days after sowing) (Sheoran et al. 1990). However, the mechanism of this phenomenon is unknown. The production of reactive oxygen species in plant cells is another universal mechanism of heavy metal toxicity. Plants respond to oxidative stress by elevating the activity of the antioxidant enzymes of the ascorbate-glutathione cycle, such as catalase, peroxidase, superoxide dismutase, glutathione reductase, and ascorbate oxidase, which protect plant cells against free radicals (Das et al. 1978; Seregin and Ivanov 2001; Pandolfini et al. 1992). The effect of
$\mathrm{Ni}^{2+}$ on antioxidant enzyme activities may differ for accumulator and non-accumulator plant species. When the non-accumulator, A. maritimum were grown in nutrient solution containing $\mathrm{Ni}$, the activities of superoxide dismutase, ascorbate peroxidase, and glutathione reductase were enhanced, whereas these activities were diminished in the hyper accumulator $A$. argenteum, and activity of superoxide dismutase was completely inhibited (Schickler and Caspi 1999). The tolerance to $\mathrm{Ni}$ in the hyper accumulators seems to employ other detoxification mechanisms for $\mathrm{Ni}$ so that $\mathrm{Ni}$ content is diminished in the cytoplasm, and the demand for antioxidant enzyme activities is alleviated. We conclude that, at high Ni concentrations, most of enzyme activities were diminished, whereas some activities, especially those of the antioxidant enzymes, increased. In most cases, we do not know whether these changes in enzyme activities stem directly from $\mathrm{Ni}^{2+}$ effects, such as binding to SH-groups or histidine or displacing the metals from metal-enzyme active centers, or indirectly, when mediated by the chain of reactions that affect the expression of the corresponding genes or exhaust their substrate pools. The inhibition of enzyme activities by heavy metals is one of the causes of declining cell metabolism (Table 3).

\section{Toxicity mechanisms of $\mathrm{Ni}$ in plants}

Although $\mathrm{Ni}$ toxicity in plants has been extensively reported, the detailed mechanisms involved are still poorly understood (Gajewska and Sklodowska 2007). The toxicity of $\mathrm{Ni}$ is likely to be caused by indirect mechanisms, because it is not an active or redox metal. Based on analyses of the available data, we propose two mechanisms of $\mathrm{Ni}$ toxicity in plants: interference with other essential metal ions and induction of oxidative stress.

Interference with other essential metal ions

It is well known that $\mathrm{Ni}$ and a range of other metals such as $\mathrm{K}, \mathrm{Na}, \mathrm{Ca}, \mathrm{Mg}, \mathrm{Fe}, \mathrm{Cu}, \mathrm{Zn}$, and $\mathrm{Mn}$ are essential for plant growth (Taiz and Zeiger 2002). Ni has some similar characteristics to $\mathrm{Ca}, \mathrm{Mg}, \mathrm{Mn}, \mathrm{Fe}, \mathrm{Cu}$, and $\mathrm{Zn}$. Therefore, $\mathrm{Ni}$ may compete with these metals in the absorption and transpiration processes (Kochian 1991; Kupper et al. 1996). As a result of competition, $\mathrm{Ni}$ at high concentrations may inhibit the absorption of these metals, decreasing their concentration and even leading to their deficiency in plants (Ahmad et al. 2007; Van Assche and Glijsters 1990; Rubio et al. 1994). Subsequently, this may affect important physiological processes, and ultimately result in toxic effects (Gajewska et al. 2006; Gon_alves 2007). For example, Ni can decrease $\mathrm{Mg}$ (or Fe) uptake and its supply 
Table 3 Nickel effects on enzymatic activity (Seregin and Kozhevnikova 2006b)

\begin{tabular}{|c|c|c|c|c|c|}
\hline Enzyme & Process & $\begin{array}{l}\text { Concentration } \\
\mathrm{Ni}, \mathrm{mM}\end{array}$ & $\begin{array}{l}\text { Enzyme } \\
\text { activity }\end{array}$ & Plant species & Source \\
\hline Rubisco & $\mathrm{CO}_{2}$ fixation & $0.5 ; 1$ & Decrease & C. cajan & Sheoran et al. (1990) \\
\hline $\begin{array}{l}\text { Glyceraldehyde 3-phosphate } \\
\text { dehydrogenase }\end{array}$ & Calvin cycle & $0.5 ; 1$ & Decrease & C. cajan & Sheoran et al. (1990) \\
\hline 3-Phosphoglycerate kinase & Calvin cycle & $0.5 ; 1$ & Decrease & C. cajan & Sheoran et al. (1990) \\
\hline Aldolase & Calvin cycle & $0.5 ; 1$ & Decrease & C. cajan & Sheoran et al. (1990) \\
\hline Fructose 1,6-bisphosphatase & Calvin cycle & $0.5 ; 1$ & Decrease & C. cajan & Sheoran et al. (1990) \\
\hline $\begin{array}{l}\text { NADP- and NAD-dependent } \\
\text { phosphoglyceraldehyde } \\
\text { dehydrogenases }\end{array}$ & Calvin cycle & $0.5 ; 1$ & Decrease & C. cajan & Sheoran et al. (1990) \\
\hline Nitrate reductase & Nitrate reduction & 1 & Decrease & B. vulgaris & $\begin{array}{l}\text { Kevresan et al. } \\
\text { (1998) }\end{array}$ \\
\hline $\mathrm{H}^{+}$-ATPase & Ion transport & 0.5 & Increase & O. sativa & Ros et al. (1990) \\
\hline Glutamine synthetase & Glutamine synthesis & 1 & Decrease & B. vulgaris & $\begin{array}{l}\text { Kevresan et al. } \\
\text { (1998) }\end{array}$ \\
\hline Alanine aminotransferase & $\begin{array}{l}\text { Transformation of } \\
\text { alanine into pyruvate }\end{array}$ & 0.2 & Decrease & Glycine max & $\begin{array}{l}\text { El-Shintinawy and } \\
\text { El-Ansary (2000) }\end{array}$ \\
\hline IAA oxidase & IAA oxidation & $\begin{array}{l}<0.05 \\
>0.05\end{array}$ & $\begin{array}{l}\text { Increase } \\
\text { Decrease }\end{array}$ & O. sativa & Das et al. (1978) \\
\hline Glutathione reductase & Glutathione reduction & $0.01-1$ & Increase & $\begin{array}{l}\text { Allysum maritimum, } \\
\text { A. argenteum }\end{array}$ & $\begin{array}{l}\text { Schickler and Caspi } \\
\text { (1999) }\end{array}$ \\
\hline Ascorbate exidase & Ascorbate oxidation & $\begin{array}{l}<0.05 \\
>0.05\end{array}$ & $\begin{array}{l}\text { Increase } \\
\text { Decrease }\end{array}$ & O. sativa & Das et al. (1978) \\
\hline Superoxide dismutase & $\mathrm{O} 2^{--}$deactivation & $\begin{array}{l}0.01 \\
0.1\end{array}$ & $\begin{array}{l}\text { Decrease } \\
\text { Increase }\end{array}$ & Allysum maritimum & $\begin{array}{l}\text { Schickler and Caspi } \\
\text { (1999) }\end{array}$ \\
\hline Catalase & $\mathrm{H} 2 \mathrm{O} 2$ degradation & $\begin{array}{l}<0.05 \\
>0.05\end{array}$ & $\begin{array}{l}\text { Increase } \\
\text { Increase }\end{array}$ & O. sativa & Das et al. (1978) \\
\hline Peroxidase & Polyphenolic oxidation & $1-40$ & Increase & T. aestivum & $\begin{array}{l}\text { Pandolfini et al. } \\
\text { (1992) }\end{array}$ \\
\hline
\end{tabular}

to aerial parts via competition, and then induce deficiencies of these elements in plants. This can result in the retardation of germination, growth suppression, and reductions in yields (Madhava Rao and Sresty 2000; Seregin and Kozhevnikova 2006a, b). These inhibitory effects of $\mathrm{Ni}$ on the growth of plants can be reduced by supplying additional Mg (or Fe) ions (Genrich et al. 1998; Gon_alves 2007; Ouzounidou et al. 2006). Therefore, Ni toxicity in plants is partly due to interference with other essential metal ions. In addition, $\mathrm{Ca}^{2+}$ has been shown to reduce the toxic effects of $\mathrm{Ni}^{2+}$ on root development in Alyssum bertolonii Desv. (Gabbrielli and Pandolfini 1984), while $\mathrm{Cu}$ seemed to increase Ni toxicity in terms of reduced vitality and growth of Scots pine (Nieminen 2004). Many enzymes, such as superoxide dismutase (SOD) and catalase (CAT), are metalloenzymes containing $\mathrm{Fe}, \mathrm{Cu}, \mathrm{Zn}$, or $\mathrm{Mn}$ in their prosthetic groups. Since excess $\mathrm{Ni}$ has been shown to decrease the contents of Fe (Pandey and Sharma 2002), Cu and $\mathrm{Zn}$ (Parida et al. 2003) in plant tissues, it is speculated that $\mathrm{Ni}$ may reduce the biosynthesis of these metalloenzymes by causing deficiencies of these essential metals
(Gajewska et al. 2006). Further studies on photosynthesis in plant leaves suggest that $\mathrm{Ni}$ can competitively remove $\mathrm{Ca}$ ions from the Ca-binding site in the oxygen evolution complex (Boisvert 2007) and replace the $\mathrm{Mg}$ ion of chlorophyll (Kupper et al. 1996; Souza and Rauser 2003; Solymosi 2004) which may eventually inhibit the PSII electron transport chain.

Induction of oxidative stress

Increasing evidence suggests that $\mathrm{Ni}$ toxicity in plants is also associated with oxidative stress (Madhava Rao and Sresty 2000; Gajewska et al. 2006; Boominathan and Doran 2002; Gonnelli et al. 2001). Excessive Ni leads to significant increases in the concentration of hydroxyl radicals, superoxide anions, nitric oxide and hydrogen peroxide (Boominathan and Doran 2002; Stohs et al. 2001; Hao et al. 2006). Since Ni is not a redox-active metal, it cannot directly generate these reactive oxygen species (ROS). However, it interferes indirectly with a number of antioxidant enzymes (Pandey and Sharma, 2002; 
Pandolfini et al. 1992; Baccouch et al. 2001; Gajewska and Sklodowska 2005), for example, SOD, CAT, glutathione peroxidase (GSH-Px), glutathione reductase (GR), peroxidase (POD), guaiacol peroxidase (GOPX), and ascorbate peroxidase (APX). Exposure of plants to $\mathrm{Ni}$ at low concentrations $(=0.05 \mathrm{mM})$ and/or for short times has been shown to increase the activities of SOD, POD, GR, and GOPX to enhance the activation of other antioxidant defences and hence lead to the removal (or scavenging) of ROS (Freeman 2004; Gomes-Juniora 2006). However, excess Ni has been found to reduce the activity of many cellular antioxidant enzymes, both in vitro and in vivo, and plant's capability to scavenge ROS, leading to ROS accumulation and finally oxidative stress in plants (Zhao et al. 2008; Del Carmen et al. 2002).

The activity of antioxidant enzymes may vary with the duration and type of stress treatment, and between plant species (and plant parts). For instance, in experiments by Gajewska and Sklodowska (2007), SOD and CAT activities decreased significantly in the leaves of wheat plants in response to $100(1 \mathrm{M}) \mathrm{Ni}$ treatment for 3, 6 and 9 days, whereas GSH-Px, GOPX and APX activities were increased. However, the same authors (Gajewska and Sklodowska 2005) found that exposure of 14-day-old pea plants to $\mathrm{Ni}(10,100,200 \mathrm{ml}$ for 1, 3, 6 and 9 days) resulted in reductions in SOD activities in both leaves and roots, and APX activity in roots, together with increases in APX activity in leaves, increases in glutathione S-transferase (GST) activities in both leaves and roots (most pronounced in roots), while CAT activity generally remained unchanged. $\mathrm{Ni}$ at $0.5 \mathrm{mM}$ concentration increased the activities of SOD, GR and POD and decreased the activity of CAT in 6-day-old seedlings of pigeonpea (C. cajan L. Millspaugh) (Madhava Rao and Sresty 2000). CAT and POD activities in leaves decreased significantly after cabbage was treated with $0.5 \mathrm{mM}$ Ni for 8 days (Pandey and Sharma 2002). The same tendency was found for SOD, CAT and POD activities in leaves of $\mathrm{Hy}$ drocharis dubia in response to $0.5,1,2,3,4 \mathrm{mM} \mathrm{Ni}$ treatments for 3 days (Papadopoulos 2007). Ni has also been shown to increase the plasma membrane (PM) NADPH oxidase, which was shown to be involved in Niinduced ROS generation in roots of 5-day-old wheat seedlings (Triticum durum) (Hao et al. 2006). ROS have been shown to damage cell membrane, proteins, lipids and DNA (causing, inter alia, DNA base oxidation, DNA protein cross-links, DNA gaps and breaks), resulting in lipid peroxidation (Boominathan and Doran 2002; Baccouch et al. 2001), developmental defects and genetic instability in plant species (Oller et al. 1997; Bal and Kasprzak 2002; Papazoglou et al. 2005). For example, malondialdehyde (MDA, a lipid peroxidation product) content in roots and shoots increased, when pigeon pea plants were treated with 0.5 to $1.5 \mathrm{mM} \mathrm{Ni}$ (Madhava Rao and Sresty 2000). Similar results have also been reported in corn, wheat and Alyssum species (Baccouch et al. 2001; Schickler and Caspi 1999; Dietz et al. 1999). In addition, $\mathrm{Ni}$-induced depletion of low molecular weight proteins, such as GSH, may contribute to the induction of oxidative stress in plants (Madhava Rao and Sresty 2000; Kukkola et al. 2000).

\section{Concluding remarks}

This review provides quick access to aspects related to the essentiality of $\mathrm{Ni}$ in proper growth and development of the plants. $\mathrm{Ni}$ in adequate quantities has vital roles in a wide range of morphological and physiological functions, starting from germination to the productivity. Moreover, plants cannot complete their life cycle without adequate supply of this metal. Excess Ni toxicity is illustrated by the inhibition of lateral root development, photosynthesis, mineral nutrition and enzymatic activity and it is in this aspect where Ni toxicity differs from that of other heavy metals such as $\mathrm{Ag}, \mathrm{Cd}, \mathrm{Pb}, \mathrm{Zn}, \mathrm{Cu}, \mathrm{Co}$, and $\mathrm{Hg}$. Thus, one of our future challenges to understand $\mathrm{Ni}$ role in plants would be to unravel the complete picture of translocation, partitioning and required amounts at different stages of plant development.

\section{Future perspectives}

1. Although many studies focused on the toxic effects of $\mathrm{Ni}$ on plants, the detailed mechanisms involved at both protein and molecular levels are poorly understood and require further indepth research.

2. Nickel is an essential element to plants which involves urea metabolization process. $\mathrm{Ni}$ presence also enhances seed germination and seedling vigor and the reasons yet to be explored.

3. The interaction of $\mathrm{Ni}$ with the other plant nutrients in plants is very little known and some of the studies must be devoted in this direction to understand fully the role of $\mathrm{Ni}$ in plants.

4. Ni pollution is a serious environmental concern which led to research on phytoremediation. However, studies are needed to know the details at both biochemical and molecular levels to understand the $\mathrm{Ni}$ tolerance of $\mathrm{Ni}$ hyperaccumulators.

Acknowledgments The authors are thankful to Dr. Gary, Research Scientist, Centre for Environmental Risk Assessment and Remediation (CERAR), University of South Australia, SA for his valuable suggestions during the preparation of this manuscript. 


\section{References}

Ahmad MSA, Hussain M, Saddiq R, Alvi AK (2007) Mungbean: a nickel indicator, accumulator or excluder? Bull Environ Contam Toxicol 78:319-324

Amosova NV, Tazina IA, Synzynys BI (2003) Effect of phytotoxicity and genotoxicity of iron, cobalt, and nickel ions on physiological parameters in plants of different species. S-kh Biol 5:49-54

Arnon DI, Stout PR (1939) The essentiality of certain elements in minute quantity for plants with special reference to copper. Plant Physiol 14:371-375

Ayvaz Z (1992) Çevre Kirliligi ve Kontrolü. Paper presented at the meeting of E.Ü.1. Uluslararas çevre koruma sempozyumu, Izmir

Baccouch S, Chaoui A, Ferjani EE (2001) Nickel toxicity induces oxidative damage in Zea mays roots. J Plant Nutr 24:1085-1097

Bal W, Kasprzak KS (2002) Induction of oxidative DNA damage by carcinogenic metals. Toxicol Lett 127:55-62

Barber SA (1984) Soil nutrient bioavailability: a mechanistic approach. Wiley, New York

Barrie LA (1981) Atmospheric nickel in Canada. In: Effects of nickel in the Canadian environment. National Research Council of Canada No. 18568. 3, Ottawa, pp 55-76

Barsukova VS, Gamzikova OI (1999) Effects of nickel surplus on the element content in wheat varieties contrasting in Ni resistance. Agrokhimiya 1:80-85

Bishnoi NR, Sheoran IS, Singh R (1993) Influence of cadmium and nickel on photosynthesis and water relations in wheat leaves of different insertion level. Photosynthetica 28:473-479

Boisvert S (2007) Inhibition of the oxygen-evolving complex of photosystem II and depletion of extrinsic polypeptides by nickel. Biometals 20:879-889

Boominathan R, Doran PM (2002) Ni-induced oxidative stress in roots of the $\mathrm{Ni}$ hyperaccumulator, Alyssum bertolonii. New Phytol 156:205-215

Carlson RW, Bazzaz FA, Rolfe GL (1975) The effect of heavy metals on plants: II. Net photosynthesis and transpiration of whole corn and sunflower plants treated with $\mathrm{Pb}, \mathrm{Cd}, \mathrm{Ni}$ and Ti. Environ Res 10:113-120

Cempel M, Nikel G (2006) Nickel: a review of its sources and environmental toxicology. Polish J Environ Stud 15:375-382

Chen C, Huang D, Liu J (2009) Functions and toxicity of nickel in plants: recent advances and future prospects. Clean 37: 304-313

Crooke WM (1958) Effect of heavy metal toxicity on the cation exchange capacity of plant roots. Soil Sci 86:231-241

Das PK, Kar M, Mishra D (1978) Nickel nutrition of plants: effect of nickel on some oxidase activities during rice (Oryza sativa L.) seed germination. Z Pflanzenphysiol 90:225-233

De kock PC (1956) Heavy metal toxicity and iron chlorosis. Ann Bot 20:133-141

Del Carmen EM, Souza V, Bucio L, Hernández E, DamiánMatsumura P, Zaga V, Gutiérrez-Ruiz MC (2002) Cadmium induces alpha(1) collagen (I) and metallothionein II gene and alters the antioxidant system in rat hepatic stellate cells. Toxicology 170:63-73

Denkhaus E, Salnikow K (2002) Nickel essentiality, toxicity, and carcinogenicity. Crit Rev Oncol Hematol 42:35-56

Dietz KJ, Baier M, Kramer U (1999) Ecophysiology of plant growth under heavy metals. In: Prasad MNV, Hagemeyer J (eds) Heavy metal stress in plants: from molecules to ecosystems. Springer, Berlin, pp 73-97

Dimkpa C, Svatos A, Merten D, Buchel G, Kothe E (2008) Hydroxamate siderophores produced by Streptomyces acidiscabies $\mathrm{E} 13$ bind nickel and promote growth in cowpea (Vigna unguiculata $\mathrm{L}$.) under nickel stress. Can J Microbiol 54:163-172
Duke JM (1980) Production and uses of nickel. In: Nriagu JO (ed) Nickel in the environment. Wiley, New York, pp 51-65

Eisler R (1998) Nickel hazards to fish, wildlife, and invertebrates: a synoptic review. Biological science report USGS/BRD/BSR1998-0001, Patuxent Wildlife Research Center, U.S. Geological Survey, Laurel, MD 20708

El-Shintinawy F, El-Ansary A (2000) Differential effect of $\mathrm{Cd}^{2+}$ and $\mathrm{Ni}^{2+}$ on amino acid metabolism in soybean seedlings. Biol Plant 43:79-84

Emsley J (1991) The elements. Clarendon, Oxford

Ewais EA (1997) Effects of cadmium, nickel and lead on growth, chlorophyll content and proteins of weeds. Biol Plant 39: 403-410

Foy CD, Chaney RL, White MC (1978) The physiology of metal toxicity in plants. Ann Rev Plant Physiol 29:511-566

Freeman JL (2004) Increased glutathione biosynthesis plays a role in nickel tolerance in Thlaspi nickel hyperaccumulators. Plant Cell 16:2176-2191

Gabbrielli R, Pandolfini T (1984) Effect of $\mathrm{Mg}^{2+}$ and $\mathrm{Ca}^{2+}$ on the response to nickel toxicity in a serpentine endemic and nickelaccumulating species. Physiol Plant 62:540-544

Gajewska E, Sklodowska M (2005) Antioxidative responses and proline level in leaves and roots of pea plants subjected to nickel stress. Acta Physiol Plant 27:329-339

Gajewska E, Sklodowska M (2007) Effect of nickel on ROS content and antioxidative enzyme activities in wheat leaves. Biometals 20:27-36

Gajewska E, Sklodowska M, Slaba M, Mazur J (2006) Effect of nickel on antioxidative enzyme activities, proline and chlorophyll contents in wheat shoots. Biol Plant 50:653-659

Genrich I, Burd GI, Dixon DG, Glick BR (1998) A plant growthpromoting bacterium that decreases nickel toxicity in seedlings. Appl Environ Microbiol 64:3663-3668

Gomes-Juniora RA (2006) Nickel elicits a fast antioxidant response in Coffea arabica cells. Plant Physiol Biochem 44:420-429

Gon_alves SC (2007) Genetic diversity and differential in vitro responses to $\mathrm{Ni}$ in Cenococcum geophilum isolates from serpentine soils in Portugal. Mycorrhiza 17:677-686

Gonnelli C, Galardi F, Gabrielli R (2001) Nickel and copper tolerance and toxicity in three Tuscan populations of Silene paradoxa. Physiol Plantarum 113:507-514

Hao F, Wang X, Chen J (2006) Involvement of plasma-membrane NADPH oxidase in nickel-induced oxidative stress in roots of wheat seedlings. Plant Sci 170:151-158

International Agency for Research on Cancer (IARC) (1976) IARC monographs on the evaluation of the carcinogenic risk of chemicals to man: cadmium, nickel, some epoxides, miscellaneous industrial chemicals and general considerations on volatile anaesthetics, vol 11. World Health Organization, IARC, Lyon, France, $306 \mathrm{pp}$

Ivanov VB (1994) Root growth responses to chemicals. Sov Sci Rev Ser D 1:70-78

Ivanov VB, Bystrova EI, Seregin IV (2003) Comparative impacts of heavy metals on root growth as related to their specificity and selectivity. Fiziol Rast 50:445-454

Izosimova A (2005) Modeling the interaction between calcium and nickel in the soil-plant system. Landbauforschung Völkenrode FAL Agricultural Research. Special Issue 288, ISBN 3-86576011-2, 100

Karataglis SS, McNeilly T, Bradshaw AD (1986) Lead and zink tolerance of Agrostis capillaris L. and Festuca rubra L. across a mine pasture boundary at Minera, North Wales. Phyton 26:65-72

Kasprzak KS (1987) Nickel. Adv Mod Environ Toxicol 11:145-183

Kasprzak KS, Sunderman Jr FW, Salnikow K (2003) Nickel carcinogenesis. Mutation Res 533:67-97 
Kevresan S, Petrovi N, Popovi M, Kandrac J (1998) Effect of heavy metals on nitrate and protein metabolism in sugar beet. Biol Plant 41:235-240

Khalid BY, Tinsley J (1980) Some effects of nickel toxicity on rye grass. Plant Soil 55:139-144

Knasmüller S, Gottmann E, Steinkellner H, Fomin A, Pickl C, Paschke A, God R, Kundi M (1998) Detection of genotoxic effects of heavy metal contaminated soils with plant bioassays. Mutation Research 420:37-48

Kochian LV (1991) Mechanisms of micronutrient uptake and translocation in plants. In: Mortvedt JJ (ed) Micronutrients in agriculture. Soil Science Society of America, Madison, WI, pp 251-270

Krupa Z, Baszynski T (1995) Some aspects of heavy metals toxicity towards photosynthetic apparatus-direct and indirect effects on light and dark reactions. Acta Physiol Plant 17:177-190

Krupa Z, Siedlecka A, Maksymiec W, Baszynski T (1993) In vitro responses of photosynthetic apparatus of Phaseolus vulgaris L. to nickel toxicity. Plant Physiol 142:664-668

Kukkola E, Rautio P, Huttunen S (2000) Stress indications in copperand nickel-exposed Scots pine seedlings. Environ Exp Bot 43:197-210

Kupper H, Kupper F, Spiller M (1996) Environmental relevance of heavy metal-substituted chlorophylls using the example of water plants. J Exp Bot 47:259-266

L'Huillier L, d'Auzac J, Durand M, Michaud-Ferriere N (1996) Nickel effects on two maize (Zea mays) cultivars: growth, structure, ni concentration and localization. Can J Bot 74:1547-1554

Liu D, Jiang W, Wang W, Zhai L (1995) Evaluation of metal ion toxicity on root tip cells by the allium test. Israel J Plant Sci 43:125-133

Madhava Rao KV, Sresty TV (2000) Antioxidative parameters in the seedlings of pigeonpea (Cajanus cajan (L.) Millspaugh) in response to Zn and Ni stresses. Plant Sci 157:113-128

Maksymiec W (1997) Effect of copper on cellular processes in higher plants. Photosynthetica 34:321-342

Mohanty N, Vaas I, Demeter S (1989) Impairment of photosystem 2 activity at the level of secondary quinone electron acceptor in chloroplasts treated with cobalt, nickel and zinc ions. Physiol Plant 76:386-390

Molas J (1997) Changes in morphological and anatomical structure of cabbage (Brassica oleracea L.) outer leaves and in ultrastructure of their chloroplasts caused by an in vitro excess of nickel. Photosynthetica 34:513-522

Muhammad Sajid AA, Muhammad A (2012) Essential roles and hazardous effects of nickel in plants. Rev Environ Cont Toxicol 214:125-167

Nagajyoti PC, Lee KD, Sreekanth TVM (2010) Heavy metals, occurrence and toxicity for plants: a review. Environ Chem Lett 8:199-216

National Academy of Sciences (NAS) (1975) Nickel. Medical and biological effects of environmental pollutants. National Research Council, National Academy of Sciences, Washington

Neiboer E, Richardson DHS (1980) The replacement of the nondescriptive term "heavy metals" by a biologically and chemically significant classification of metal ions. Environ Pollut 1:3-26

Nieboer E, Nriagu JO (eds) (1992) Nickel and human health: current perspectives. Wiley, New York

Nieminen TM (2004) Effects of soil copper and nickel on survival and growth of Scots pine. J Environ Monit 6:888-896

Nriagu JO (1980) Global cycle and properties of nickel. In: Nriagu JO (ed) Nickel in the environment. Wiley, New York, pp 1-26

Oller AR, Costa M, Oberdorster G (1997) Carcinogenicity assessment of selected nickel compounds. Toxcol Appl Pharmacol 143:152-166
Ouzounidou G, Moustakas M, Symeonidis L, Karataglis S (2006) Response of wheat seedlings to Ni stress: effects of supplemental calcium. Arch Environ Contam Toxicol 50:346-352

Pallavi S, Ram Shankar D (2005) Lead toxicity in plants. Braz J Plant Physiol 17:35-52

Pandey N, Sharma CP (2002) Effect of heavy metals $\mathrm{Co}^{2+}, \mathrm{Ni}^{2+}$ and $\mathrm{Cd}^{2+}$ on growth and metabolism of cabbage. Plant Sci 163: $753-758$

Pandolfini T, Gabbrielli R, Comparini C (1992) Nickel toxicity and peroxidase activity in seedlings of Triticum aestivum L. Plant Cell Environ 15:719-725

Papadopoulos A (2007) Determination and evaluation of cadmium, copper, nickel, and zinc in agricultural soils of western Macedonia, Greece. Environ Manag 40:719-726

Papazoglou EG, Karantounias GA, Vemmos SN, Bouranis DL (2005) Photosynthesis and growth responses of giant reed (Arundo donax L.) to the heavy metals $\mathrm{Cd}$ and $\mathrm{Ni}$. Environ Int 31:243-249

Parida BK, Chhibba IM, Nayyar VK (2003) Influence of nickelcontaminated soils on fenugreek (Trigonella corniculata L.) growth and mineral composition. Sci Hortic 98:113-119

Piccini DF, Malavolta E (1992) Effect of nickel on two common bean cultivars. J Plant Nutr 15:2343-2350

Robertson AI, Meakin MER (1980) The effect of nickel on cell division and growth of Brachystegia spiciformis seedlings. J Bot Zimb 12:115-125

Ros R, Cooke DT, Burden RS, James CS (1990) Effects of the herbicide MCPA, and the heavy metals, cadmium and nickel on the lipid composition, $\mathrm{Mg}^{2+}$-ATPase activity and fluidity of plasma membranes from rice, Oryza sativa (cv. Bahia) shoots. J Exp Bot 41:457-462

Ros R, Morales A, Segura J, Picazo I (1992) In vivo and in vitro effects of nickel and cadmium on the plasmalemma ATPase from rice (Oryza sativa L.) shoots and roots. Plant Sci 83:1-6

Rubio MI, Escrig I, Martinez-Cortina C, Lopez-Benet FJ, Sanz A (1994) Cadmium and nickel accumulation in rice plants. effects on mineral nutrition and possible interactions of abscisic and gibberellic acids. Plant Growth Regul 14:151-157

Samantaray S, Rout GR, Das P (1997) Tolerance of rice to nickel in nutrient solution. Biol Plant 40:295-298

Schickler H, Caspi H (1999) Response of antioxidative enzymes to nickel and cadmium stress in hyperaccumulator plants of genus, Alyssum. Physiol Plant 105:39-44

Seregin IV, Ivanov VB (1997) Is the endodermal barrier the only factor preventing the inhibition of root branching by heavy metal salts? Fiziol Rast (Moscow) 44:922-925

Seregin IV, Ivanov VB (1998) The transport of cadmium and lead ions through root tissues. Fiziol Rast 45:899-905

Seregin IV, Ivanov VB (2001) Physiological Aspects of cadmium and lead toxic effects on higher plants. Russ J Plant Physiol 48:523-544

Seregin IV, Kozhevnikova AD (2005) Distribution of cadmium, lead, nickel, and strontium in imbibing maize caryopses. Russ J Plant Physiol 52:565-569

Seregin IV, Kozhevnikova AD (2006a) Physiological role of nickel and its toxic effects on higher plants. Fiziol Rast 53:285-308

Seregin IV, Kozhevnikova AD (2006b) Physiological role of nickel and its toxic effects on higher plants. Russ J Plant Physiol 53:257-277

Seregin IV, Kozhevnikova AD, Kazyumina EM, Ivanov VB (2003) Nickel toxicity and distribution in maize roots. Fiziol Rast 50:793-800

Sheoran IS, Singal HR, Singh R (1990) Effect of cadmium and nickel on photosynthesis and the enzymes of the photosynthetic carbon reduction cycle in pigeonpea (Cajanus cajan L.). Photosynth Res 23:345-351 
Solymosi K (2004) Depending on concentration, $\mathrm{Hg}^{2+}$ reacts with different components of the NADPH: protochlorophyllide oxidoreductase macrodomains. Plant Biol 6:358-363

Souza JF, Rauser WE (2003) Maize and radish sequester excess cadmium and zinc in different ways. Plant Sci 65:1009-1022

Sresty TVS, Madhava Rao KV (1999) Ultrastructural alterations in response to zinc and nickel stress in the root cells of pigeon pea. Environ Exp Bot 41:3-13

Stohs SJ, Bagchi D, Hassoun E, Bagchi M (2001) Oxidative mechanisms in the toxicity of chromium and cadmium ions. J Environ Pathol Toxicol Oncol 20:77-88

Taiz L, Zeiger E (2002) Plant Physiology, 3rd edn. Sinauer Associates, Sunderland, pp 607-611

Van Assche F, Glijsters H (1990) Effects of metals on enzyme activity in plants. Plant Cell Environ 13:195-206

Veeranjaneyulu K, Das VSR (1982) Intrachloroplast localization of $65 \mathrm{Zn}$ and $63 \mathrm{Ni}$ in a $\mathrm{Zn}$-tolerant plant, Ocimum basilicum benth. J Exp Bot 33:1161-1165
Wang W (1987) Root elongation method for toxicity testing of organic and inorganic pollutants. Environ Toxicol Chem 6:409-414

Wong MH, Bradshaw AD (1982) A comparison of the toxicity of heavy metals, using root elongation of rye grass, Lolium perrene. New Phytol 91:255-261

World Health Organization (WHO) (1991) Nickel: environmental health criteria, vol 108. World Health Organization, Geneva

Yusuf M, Fariduddin Q, Hayat S, Ahmad A (2011) Nickel: an overview of uptake, essentiality and toxicity in plants. Bull Environ Contam Toxicol 86:1-17

Zhao J, Shi G, Yuan Q (2008) Polyamines content and physiological and biochemical responses to ladder concentration of nickel stress in Hydrocharis dubia (B1.) Backer leaves. Biometals 21:665-674

Zornoza P, Robles S, Martin N (1999) Alleviation of nickel toxicity by ammonium supply to sunflower plants. Plant Soil 208: $221-226$ 